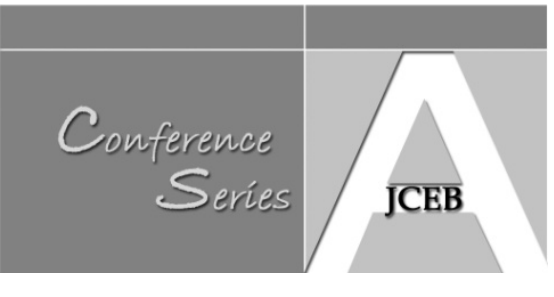

\title{
A Competency Knowledge-Base for BIM Learning
}

Bilal Succar (ChangeAgents AEC, Australia)

Willy Sher (University of Newcastle, Australia)

\begin{abstract}
Building Information Modelling (BIM) tools and workflows continue to proliferate within the Design, Construction and Operation (DCO) industry. To equip current and future industry professionals with the necessary knowledge and skills to engage in collaborative workflows and integrated project deliverables, it is important to identify the competencies that need to be taught at educational institutions or trained on the job. Expanding upon a collaborative BIM education framework pertaining to a national BIM initiative in Australia, this paper introduces a conceptual workflow to identify, classify, and aggregate BIM competency items. Acting as a knowledge-base for BIM learners and learning providers, the aggregated competency items can be used to develop BIM learning modules to satisfy the learning requirements of varied audiences - be they students, practitioners, tradespeople or managers. This competency knowledge-base will facilitate a common understanding of BIM deliverables and their requirements, and support the national efforts to promote BIM learning.
\end{abstract}

Keywords: BIM competency, BIM education, BIM learning modules, competency knowledge-base, learning triangle.

\section{Introduction}

Building Information Modelling (BIM) is the current expression of technical and procedural innovation within the construction industry. It is a methodology for generating, exchanging and managing a constructed facility's data throughout its life cycle. While BIM is solidly rooted in technological advances, partially transferred from other industries, it extends into the realm of social exchanges between organizational actors. As a transformative approach to designing, constructing and operating in the built environment, BIM includes a wide range of concepts, tools and workflows which need to be learned and applied by industry stakeholders.

To equip current and future industry professionals with the necessary knowledge and skills to engage in collaborative BIM workflows and integrated project deliverables, it is first important to identify the competencies that need to be taught at educational institutions or trained on the job. Also, to facilitate the development of BIM learning modules addressing both the specific and common requirements of a variety of learners, a large inventory of wellstructured competencies is needed.

This paper first introduces the collaborative BIM education framework developed by a joint industry/academia initiative in Australia in 2011-2012. It then focuses on the first three components within the framework to align our research efforts in developing a BIM competency knowledge-base to facilitate BIM learning. In describing our efforts, we use the term BIM learning rather than BIM education to focus attention on what needs to be learned rather than on how, where and when learning occurs. We also use the term competencies to integrate the granular notions of BIM knowledge, skills and experience. 


\section{A Collaborative BIM Education Framework}

This section briefly reflects upon a national BIM initiative led by two industry associations in Australia: the Australian Institute of Architects (AIA) and Consult Australia (CA). Starting in 2011, industry stakeholders were consulted, resulting in succinct documents which covered pertinent BIM topics. In 2012, three BIM education documents were generated by a working group of eleven subject matter experts from across industry and academia. The BIM in Practice - BIM Education documents (AIA-CA, 2012) introduced twenty education principles that summarise the group's findings (Table 1 ) and a six-component collaborative BIM education framework (Table 2) that clarifies how these findings will be acted-upon:

Table 1. BIM in Practice, Education Principles (EP) - partial list

\begin{tabular}{ll}
\hline No. & Education Principle \\
\hline EP1 & BIM education is the shared responsibility of academia and industry \\
\hline EP2 & $\begin{array}{l}\text { BIM education addresses the requirements of current professionals (irrespective of formal } \\
\text { qualifications), future professionals (students) and their teachers/trainers }\end{array}$ \\
\hline EP3 & $\begin{array}{l}\text { BIM education encompasses all modes of BIM learning (tertiary courses, industry } \\
\text { workshops, online media, on-the-job training...) }\end{array}$ \\
\hline EP6 & Collaborative BIM education should be developed and delivered collaboratively \\
\hline EP8 & $\begin{array}{l}\text { BIM adoption within industry and academia is a significant change process (technical, } \\
\text { procedural, cultural...) which requires a significant investment in systems and people. }\end{array}$ \\
\hline EP9 & $\begin{array}{l}\text { Accreditation and professional associations should engage with universities to develop new } \\
\text { collaborative BIM courses or to integrate the principles and technologies of multidisciplinary } \\
\text { collaboration into their existing curricula }\end{array}$ \\
\hline EP14 & $\begin{array}{l}\text { There is a need to consider how to assess and improve the BIM knowledge, skill and } \\
\text { experience of current professionals, para-professionals and tradespeople }\end{array}$ \\
\hline EP15 & $\begin{array}{l}\text { There are many BIM competencies which need to be learned by individuals involved in the } \\
\text { design, construction and operation of facilities }\end{array}$ \\
\hline EP16 & $\begin{array}{l}\text { A collaborative CPD programme is an integral part of the collaborative BIM education } \\
\text { framework }\end{array}$ \\
\hline EP17 & $\begin{array}{l}\text { A web-hosted, socially-connected BIM learning hub - at the core of the collaborative BIM } \\
\text { education framework - is needed }\end{array}$ \\
\hline EP18 & $\begin{array}{l}\text { A BIM learning module is a collection of BIM topics, customised for a target audience, and } \\
\text { delivered at a defined level of difficulty }\end{array}$ \\
\hline EP19 & $\begin{array}{l}\text { An academic framework informed by research, discipline professionals and other industry } \\
\text { stakeholders is a pre-requisite for delivering collaborative BIM education within tertiary } \\
\text { institutions }\end{array}$ \\
\hline EP20 & $\begin{array}{l}\text { The establishment of a well-structured and well-funded BIM institution is essential to } \\
\text { facilitate the development and delivery of collaborative BIM education across the } \\
\text { construction industry }\end{array}$ \\
\hline &
\end{tabular}

Succar, B \& Sher, W. 2014, ‘A Competency knowledge-base for BIM learning', Australasian Journal of Construction Economics and Building Conference Series, 2(2), 1-10. 
Table 2. The Collaborative BIM Education Framework - six components

\begin{tabular}{|c|c|c|}
\hline No. & Component & Brief description \\
\hline A & $\begin{array}{l}\text { Identifying BIM } \\
\text { competencies }\end{array}$ & $\begin{array}{l}\text { This component highlights several sources to identify BIM } \\
\text { competencies including: analysing peer-reviewed literature, and } \\
\text { collaborating with academic institutions and industry associations to } \\
\text { identify the learning requirements of their respective students and } \\
\text { members }\end{array}$ \\
\hline B & $\begin{array}{l}\text { Classifying BIM } \\
\text { competencies }\end{array}$ & $\begin{array}{l}\text { This component highlights how BIM competencies should be } \\
\text { consistently defined by developing a BIM dictionary to unify terms; a } \\
\text { taxonomy to organize competencies; and a faceted classification } \\
\text { (e.g. roles, disciplines, difficulty levels and delivery methods) to filter } \\
\text { competencies according to target audiences }\end{array}$ \\
\hline C & $\begin{array}{l}\text { Developing BIM } \\
\text { learning } \\
\text { modules }\end{array}$ & $\begin{array}{l}\text { This component advocates an online BIM learning hub with a } \\
\text { database of competency items. The database serves as a knowledge } \\
\text { source for developing BIM learning modules and learning material to } \\
\text { fulfil varied educational requirements }\end{array}$ \\
\hline D & $\begin{array}{l}\text { Developing an } \\
\text { industry } \\
\text { framework for } \\
\text { professional } \\
\text { development }\end{array}$ & $\begin{array}{l}\text { This component advocates the development of a BIM education } \\
\text { cooperation framework between industry associations to allow the } \\
\text { generation and joint-delivery of collaborative BIM learning modules } \\
\text { and BIM learning material }\end{array}$ \\
\hline E & $\begin{array}{l}\text { Developing or } \\
\text { adopting an } \\
\text { academic } \\
\text { framework }\end{array}$ & $\begin{array}{l}\text { This component highlights the need for developing or adopting } 1 \text { a } \\
\text { specialised academic framework for BIM education to enable } \\
\text { academic institutions to contribute to and benefit from the BIM } \\
\text { learning hub }\end{array}$ \\
\hline $\mathbf{F}$ & $\begin{array}{l}\text { Initiating a BIM } \\
\text { institute }\end{array}$ & $\begin{array}{l}\text { This component highlights the need for a dedicated organizational } \\
\text { structure - a national BIM institute - to facilitate and promote BIM } \\
\text { learning across industry }\end{array}$ \\
\hline
\end{tabular}

The education principles (Table 1) and framework components (Table 2) summarise the findings and recommendations of the AIA/CA BIM Education working group. Building upon previous research (Succar et al., 2013), the following sections address the first three framework components by introducing an integrated definition of individual BIM competencies ${ }^{2}$; explaining how competency items are identified, classified and aggregated; clarifying the BIM learning triangle of learners, learning providers and learning spectrum; and discussing how an extendable BIM competency knowledge-base can be used to generate varied BIM learning modules.

\footnotetext{
${ }^{1}$ There are several worldwide initiatives focusing on BIM education in tertiary education including a significant research undertaking in Australia (OLT, 2010) (Macdonald, 2012)

2 For brevity, this paper doesn't differentiate competency/competencies from competence/ competences (Winterton et al., 2006)(Sanghi, 2007)(Sampson and Fytros, 2008)
}

Succar, B \& Sher, W. 2014, ‘A Competency knowledge-base for BIM learning', Australasian Journal of Construction Economics and Building Conference Series, 2(2), 1-10. 


\section{Individual BIM Competencies}

It is important to acknowledge that there is little consensus among researchers on the meaning of the term competency (Winterton et al., 2006) (Sanghi, 2007) (Hijazeh, 2011). According to Ley and Albert (2003, p. 1501), "although competencies have been considered increasingly important in HR and KM approaches, it is thus far an unresolved issue of what exactly competencies are". For the purposes of this paper, we propose an integrated definition of individual BIM competencies which acknowledges and aligns a multitude of definitions explored in Succar et al. (2013):

Individual BIM competencies are the personal traits, professional knowledge and technical abilities required by an individual to perform a BIM activity or deliver a BIMrelated outcome. These abilities, activities or outcomes must be measureable against performance standards and can be acquired or improved through education, training and/or development.

This definition includes several key points:

1. Individual BIM competencies relate specifically to the abilities of individuals (and not to the competencies of groups, organizations or teams). Individuals can be professionals, tradespeople, academics or students from any discipline, specialty, position or role

2. An individual BIM competency is the aggregate sum of three components: conceptual or theoretical knowledge (Trichet and Leclère, 2003); skill, procedural or applied knowledge (De Jong and Ferguson-Hessler, 1996); and personal traits, the "other deployment-related characteristic (e.g. attitude, behaviour, physical ability)" (HR-XML-Consortium, 2003 - p. 5)

3. A competency item - the textual descriptor of granular competency - can manifest itself in three different ways: as an ability (inert or learned) required to perform a defined activity or deliver a measureable outcome; as an activity, a set of tasks performed for the purpose of delivering a measureable outcome; and an outcome or measureable deliverable - be it a product or a service

4. BIM competencies are measureable - quantitatively or qualitatively - against performance standards

5. BIM competencies can be acquired in several ways including:

a. Formal education as typically focused on improving theoretical knowledge (e.g. learning design theory or how to calculate thermal gain)

b. Vocational or on-the-job training as typically focused on skill improvement (e.g. how to use Tekla or operate a laser scanner)

c. Professional development as typically focused on improving personal traits (e.g. self-confidence or critical thinking)

The next section clarifies how individual BIM competency items are identified, classified, and aggregated into a useable knowledge base. 


\section{BIM competency identification, classification and aggregation}

To use BIM competencies in learning, these first need to be clearly defined. This section describes a three-step approach (Figure 1) to identify, classify and aggregate competency items into a BIM competency knowledge base:

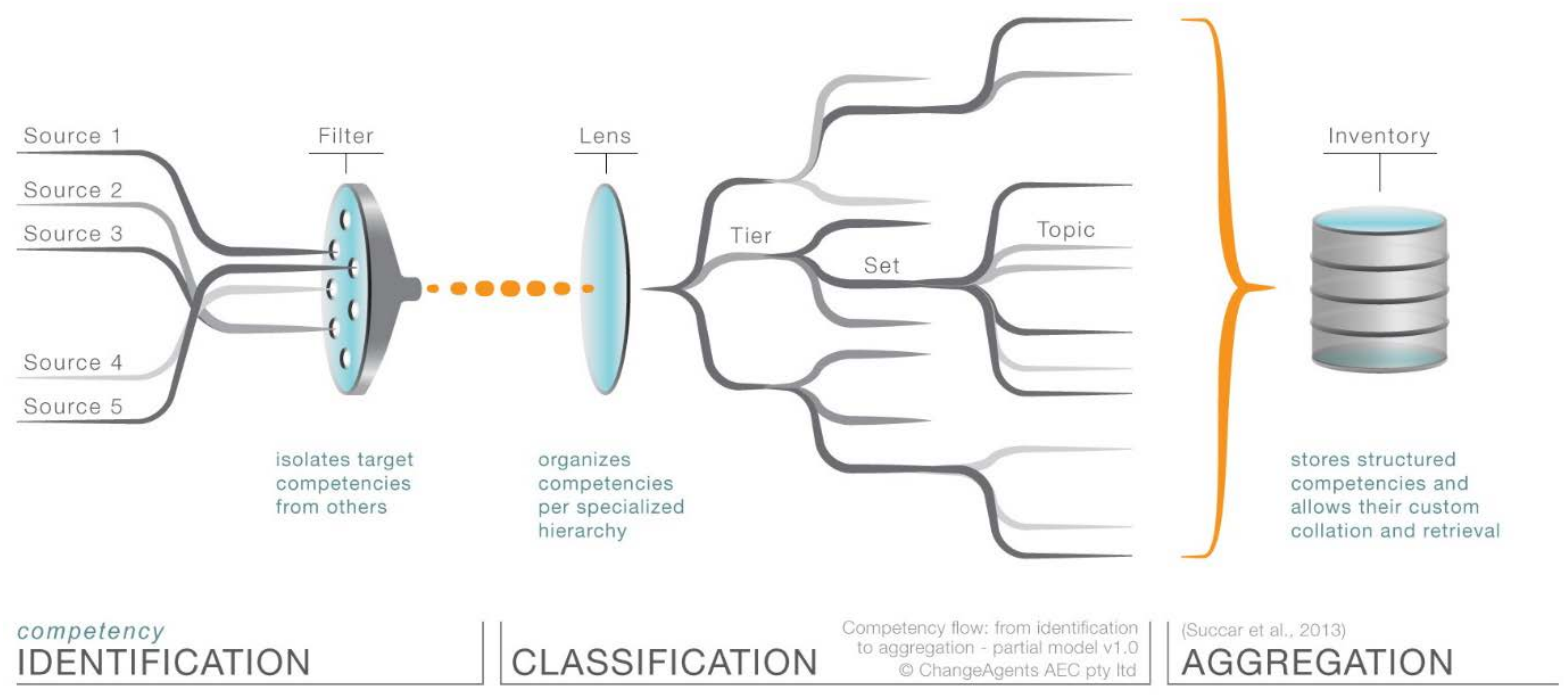

Figure 1. Competency flow diagram - partial

\section{Competency identification}

BIM competency items are first collected from multiple sources and then filtered to isolate those that satisfy the aforementioned integrated BIM competency definition. The sources used include: analysing BIM job advertisements; dissecting BIM roles defined within literature and noteworthy BIM publications (Succar, 2013); adapting competency inventories from related domains; and harvesting competency requirements from industry associations and subject matter experts.

\section{Competency classification}

The number of BIM competency items that can be collected is very large. To organize these items into useable clusters, a BIM competency taxonomy (Succar et al., 2013) is used. It includes three complementary tiers - core, domain and execution:

1. Core Tier competencies represent the personal abilities of individuals enabling them to conduct a measureable activity or deliver a measurable outcome. The core tier is subdivided into four competency sets: foundational traits; situational enablers; qualifications and licences; and historical enablers

2. Domain Tier competencies represent the professional abilities of individuals, the means they use to perform multi-task activities and the methods they employ to deliver outcomes with complex requirements. There are eight competency sets within this tier subdivided into primary sets (managerial, functional, technical, and supportive) and secondary sets (administration, operation, implementation, and research \& development) 
3. Execution Tier competencies are an individual's ability to use specific tools and techniques to conduct an activity or deliver a measureable outcome. Examples include the ability to use a software tool (e.g. a 3D model authoring tool), drive a vehicle (e.g. a 30 tonne tipper truck) or operate specialized field equipment (e.g. a laser scanner)

Competencies across the three tiers are numerous, varied yet defined using a simple standardised syntax. Table 3 provides a sample list of competency items from the domain tier:

Table 3. Sample competency items

\begin{tabular}{lll}
\hline $\begin{array}{l}\text { Competency } \\
\text { Set }\end{array}$ & $\begin{array}{l}\text { Competency } \\
\text { Topic (partial) }\end{array}$ & $\begin{array}{l}\text { Individual BIM Competency Item } \\
\text { (items defined at low-detail; expressed as activities) }\end{array}$ \\
\hline Managerial & Leadership & $\begin{array}{l}\text { Generate an overall mission statement covering BIM } \\
\text { implementation within an organization }\end{array}$ \\
\cline { 2 - 3 } & Strategic Planning & $\begin{array}{l}\text { Define the strategic objectives to be achieved from } \\
\text { implementing model-based workflows }\end{array}$ \\
\cline { 2 - 3 } Administration & $\begin{array}{l}\text { Organizational } \\
\text { Management }\end{array}$ & $\begin{array}{l}\text { Identify changes to organizational processes as } \\
\text { necessary to benefit from model-based workflows }\end{array}$ \\
\cline { 2 - 3 } & $\begin{array}{l}\text { Policies and } \\
\text { Procedures }\end{array}$ & $\begin{array}{l}\text { Organize initiatives to encourage staff to adopt BIM } \\
\text { software tools and workflows within the organization }\end{array}$ \\
\cline { 2 - 3 } & $\begin{array}{l}\text { Finance and } \\
\text { Accounting }\end{array}$ & $\begin{array}{l}\text { Establish the necessary metrics to measure the } \\
\text { financial performance of BIM projects }\end{array}$ \\
\cline { 2 - 3 } & $\begin{array}{l}\text { Human Resource } \\
\text { Management }\end{array}$ & $\begin{array}{l}\text { Identify the responsibilities of a BIM manager, a model } \\
\text { manager and similar BIM roles }\end{array}$ \\
\hline Functional & Collaboration & $\begin{array}{l}\text { Develop model ownership protocols with other project } \\
\text { participants at the start of BIM projects }\end{array}$ \\
\cline { 2 - 3 } & Facilitation & $\begin{array}{l}\text { Act as a project team's BIM facilitator during the } \\
\text { delivery of collaborative BIM projects }\end{array}$ \\
\cline { 2 - 3 } & Team and Workflow & $\begin{array}{l}\text { Use a content management system to manage } \\
\text { information storage and sharing }\end{array}$ \\
\hline
\end{tabular}

\section{Competency aggregation}

There are potentially thousands of competency items that would satisfy the integrated BIM competency definition. To enable the use and re-use of these items, a semanticallyconnected, web-based BIM competency knowledge-base has been developed ${ }^{3}$. The knowledge-base acts as a platform to collate, organize and provide access to a large number of structured competency items to facilitate competency acquisition, assessment and application ${ }^{4}$. These competency items are defined using neutral syntax; semantically connected to each other and to an online BIM dictionary; and progressively linked to elearning material collated from online sources or purposefully developed by contributing subject matter experts.

\footnotetext{
${ }^{3}$ The BIM competency knowledge-base is currently in Beta (http://BIMexcellence.org)

${ }^{4}$ Refer to the Triple A competency engine (Acquire, Assess and Apply) discussed in Succar et al. (2013) Acquire refers to competency-based learning, Assess refers to competency measurement and Apply refers to competencies applied in activities and through workflows
}

Succar, B \& Sher, W. 2014, ‘A Competency knowledge-base for BIM learning', Australasian Journal of Construction Economics and Building Conference Series, 2(2), 1-10. 
After discussing how competency items are identified classified and aggregated - thus addressing components $A$ and $B$ of the collaborative BIM education framework (refer to Table 2) - the next section clarifies how competency items are employed to facilitate BIM learning.

\section{BIM Learning}

BIM learning is the cognitive process of analysing, synthesising and evaluating ${ }^{5}$ the myriad of BIM topics required to fulfil a task or deliver a measureable outcome. As a term, BIM learning applies equally to tertiary education, vocational training, professional development and informal experiential gain. Also, it equally applies to competency-based, time-based or course-based learning models (Voorhees, 2001). Finally, BIM learning can be represented as a triangular interaction between BIM learners, BIM learning providers and the BIM learning spectrum (AIA-CA, 2012):

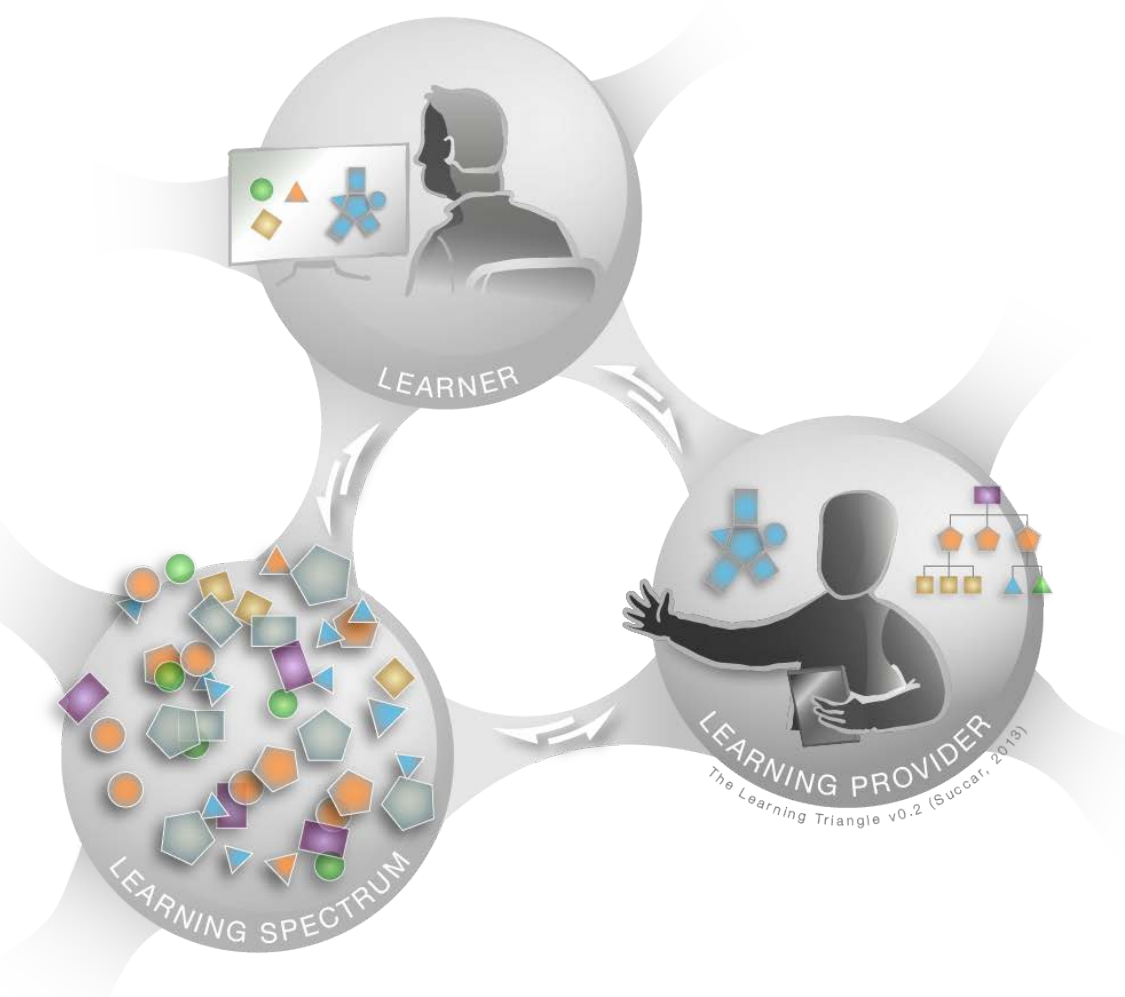

Figure 2. The (BIM) learning triangle

\section{BIM learners}

BIM learners are all individuals pursuing knowledge, skill or expertise in BIM technologies or workflows. BIM learners include practitioners and future practitioners; within any Design, Construction and Operation discipline; and at any position or role.

\footnotetext{
${ }^{5}$ For a discussion of learning and learning objectives, please refer to Bloom's Taxonomy - both original and revised - as reviewed by Krathwohl (2002) and Forehand (2010)
}

Succar, B \& Sher, W. 2014, ‘A Competency knowledge-base for BIM learning', Australasian Journal of Construction Economics and Building Conference Series, 2(2), 1-10. 


\section{BIM learning providers}

BIM learning providers are commercial and not-for-profit entities providing formal or informal BIM education, training or professional development. BIM learning providers include individual trainers, registered training organizations, universities, vocational institutions, industry association and communities of practice.

\section{BIM learning spectrum}

The BIM learning spectrum includes all BIM topics that can be learned by BIM learners or taught by BIM learning providers. The learning spectrum represents both structured and unstructured information, including well-defined, classified and aggregated BIM competency items.

\section{Using the knowledge-base to facilitate learning}

BIM competency items that meet the integrated BIM competency definition are standardised knowledge blocks that can be used in multiple ways. For the purposes of BIM learning, these items can be collated into BIM learning modules - or learning objects (Bannan-Ritland et al., 2000 ) that fulfil the requirements of varied BIM learners and varied BIM learning provides. Table 4 exemplifies how BIM competency items are collated into sample BIM learning modules:

Table 4. Sample BIM learning modules

\begin{tabular}{|c|c|}
\hline $\begin{array}{l}\text { Learning Modules (Competency } \\
\text { Tier }>\text { Set }>\text { Topic) - suggested format }\end{array}$ & $\begin{array}{l}\text { Competency } \\
\text { Items - Partial list }\end{array}$ \\
\hline \multirow{3}{*}{$\begin{array}{l}\text { Contractual Implications of Using } \\
\text { 3D Models as a Primary Source of } \\
\text { Design Information } \\
\text { (Domain>Administration>Contract } \\
\text { Management) - lecture }\end{array}$} & $\begin{array}{l}\text { Administer contracts and manage the delivery for large } \\
\text { or complex Collaborative BIM Projects }\end{array}$ \\
\hline & $\begin{array}{l}\text { Identify the most suitable Contractual Relationship for } \\
\text { different types of Collaborative BIM Projects }\end{array}$ \\
\hline & $\begin{array}{l}\text { Manage progress, compensation payments and similar } \\
\text { tasks required during collaborative BIM Projects }\end{array}$ \\
\hline \multirow{3}{*}{$\begin{array}{l}\text { Model Auditing for Model } \\
\text { Managers } \\
\text { (Domain>Technical>Model } \\
\text { Management) - online video }\end{array}$} & $\begin{array}{l}\text { Check a BIModel against common Modelling Errors } \\
\text { using manual or automated means }\end{array}$ \\
\hline & $\begin{array}{l}\text { Maintain a BIModel according to Modelling Standards } \\
\text { set by the Organization or Project Team }\end{array}$ \\
\hline & Manage BIModels on Collaborative BIM Projects \\
\hline \multirow{3}{*}{$\begin{array}{l}\text { Developing a BIM Management } \\
\text { Plan } \\
\text { (Domain>Functional>Facilitation) - } \\
\text { workshop }\end{array}$} & $\begin{array}{l}\text { Identify the BIM Deliverables and BIM Requirements of } \\
\text { each BIM project stakeholder }\end{array}$ \\
\hline & $\begin{array}{l}\text { Represent a Project's Requirements through clear } \\
\text { workflow charts, mind maps or similar }\end{array}$ \\
\hline & $\begin{array}{l}\text { Assist Project Stakeholders to make the right Mode- } \\
\text { based Workflow decisions }\end{array}$ \\
\hline
\end{tabular}

As exemplified in Table 4, competency items are used to inform the development of BIM learning modules and - by that - addressing component $C$ of the collaborative BIM education framework (Table 2). 


\section{Concluding Notes}

This paper has briefly explored the collaborative BIM education framework developed by a joint industry/academia initiative in Australia. It then clarified how the first three framework components can be addressed through a process of competency identification and classification. The paper then clarified how BIM competency items can be aggregated into a BIM competency knowledge-base which facilitates the development of BIM learning modules.

After addressing the first three components of the collaborative BIM education framework, future research will address the remaining components (Table 2). Special attention will be given to initiating a dedicated organizational structure - the BIM Institute - to connect learners to learning providers; develop BIM learning material; and facilitate the collaborative delivery of BIM education across industry and academia.

\section{References}

AIA-CA. 2012. 'BIM in Practice - BIM Education, a Position Paper by the Australian Institute of Architects and Consult Australia', available: http://www.bim.architecture.com.aul [accessed January $25,2013]$.

Bannan-Ritland, B, Dabbagh, N \& Murphy, K. 2000, 'Learning object systems as constructivist learning environments: Related assumptions, theories, and applications', The Instructional Use of Learning Objects: Online Version, 24(2.1).

De Jong, T \& Ferguson-Hessler, M.G.M. 1996, 'Types and qualities of knowledge', Educational psychologist, 31(2), 105-13.

Forehand, M. 2010, 'Bloom's taxonomy: from emerging perspectives on learning, teaching, and technology', available:

http://www4.edumoodle.at/gwk/pluginfile.php/109/mod resource/content/5/forehand bloomschetaxon omie02.pdf [accessed January 25, 2013].

Hijazeh, E.H.M. 2011, Adopting a Competency Based Human Resource Management System in Palestine Cellular Communication LTD-JAWWAL, (Masters), As-Najah National University, available: http://bit.ly/13ITkeR [accessed 2011].

HR-XML-Consortium 2003, 'Competencies (Measurable Characteristics): Recommendation', available: http://ns.hr-xml.org/2 0/HR-XML-2 0/CPO/Competencies.pdf [accessed September 16, 2012].

Krathwohl, D. R. 2002, 'A Revision of Bloom's Taxonomy: An Overview', Theory Into Practice, 41(4), 212-8.

Ley, T \& Albert, D. 2003, 'Identifying employee competencies in dynamic work domains: methodological considerations and a case study', Journal of Universal Computer Science, 9(12), 1500-18.

Macdonald, J. A. 2012, 'A Framework for Collaborative BIM Education across the AEC Disciplines', in AUBEA 2012, Sydney, AU, 4-6 July, 2012.

OLT 2010, Collaborative building design education using building information modelling (2010-2013), not published: UniSA, UON, UTS, unpublished.

Sampson, D \& Fytros, D. 2008, 'Competence Models in Technology-Enhanced Competence-Based Learning Handbook on Information Technologies for Education and Training' in Adelsberger, H. H., Kinshuk, K., Pawlowski, J. M. and Sampson, D. G., eds., Springer Berlin Heidelberg, 155-77.

Succar, B \& Sher, W. 2014, ‘A Competency knowledge-base for BIM learning', Australasian Journal of Construction Economics and Building Conference Series, 2(2), 1-10. 
Sanghi, S. 2007, The Handbook of Competency Mapping: Understanding, Designing and Implementing Competency Models in Organizations, 2nd Ed., Sage Publications, New Delhi, India.

Succar, B. 2013, BIM Knowledge Content Taxonomy v1.3, Building Information Modelling: conceptual framework and performance improvement models (PhD Thesis - submitted), School of Architecture and Built Environment, University of Newcastle, NSW Australia, unpublished.

Succar, B, Sher, W \& Williams A. 2013, 'An integrated approach to BIM competency acquisition, assessment and application (published online)', Automation in Construction, 35, 174-89.

Trichet, F \& Leclère, M. 2003, 'A Framework for Building Competency-Based Systems Dedicated to Human Resource Management' in Zhong, N., Ras, Z., Tsumoto, S. and Suzuki, E., (eds.), Foundations of Intelligent Systems, Springer, Heidelberg, Berlin, 633-9.

Voorhees, R. A. 2001, 'Competency-Based Learning Models: A Necessary Future', New Directions for Institutional Research, 2001(110), 5-13.

Winterton, J, Deist, F.D.L \& Stringfellow, E. 2006, Typology of knowledge, skills and competences: clarification of the concept and prototype, Toulouse: Research report elaborated on behalf of Cedefop/Thessaloniki, Centre for European Research on Employment and Human Resources, Group ESC Toulouse. 